2011

\title{
Maryland Lawyers Who Helped Shape the Constitution: Father of Freedom - Charles Hamilton Houston
}

José F. Anderson

University of Baltimore School of Law, janderson@ubalt.edu

Follow this and additional works at: http://scholarworks.law.ubalt.edu/all_fac

Part of the Civil Rights and Discrimination Commons

\section{Recommended Citation}

Maryland Lawyers Who Helped Shape the Constitution: Father of Freedom - Charles Hamilton Houston, 44 Md. B.J. 5 (2011)

This Article is brought to you for free and open access by the Faculty Scholarship at ScholarWorks@University of Baltimore School of Law. It has been accepted for inclusion in All Faculty Scholarship by an authorized administrator of ScholarWorks@University of Baltimore School of Law. For more information, please contact snolan@ubalt.edu. 


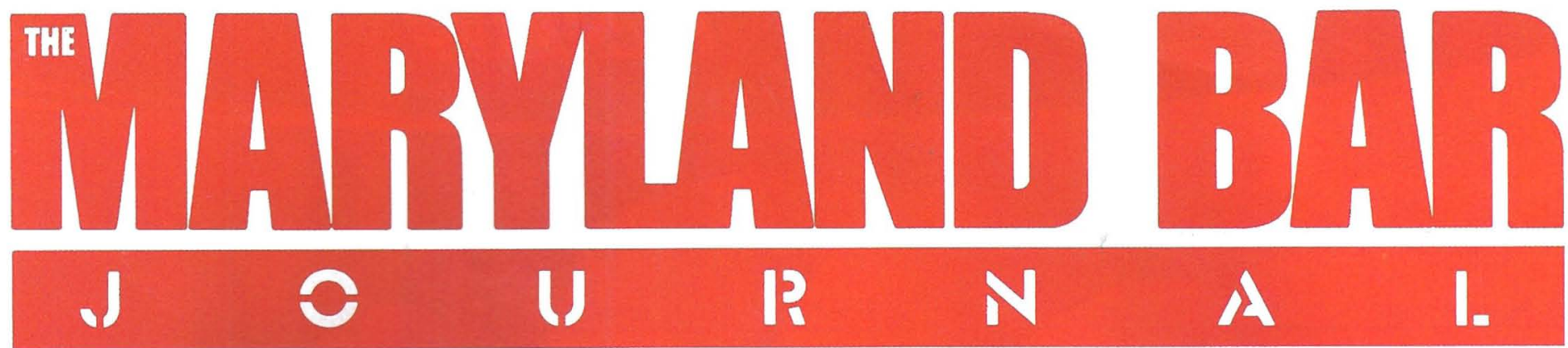

Volume XLIV • Number 4

July/August 2011

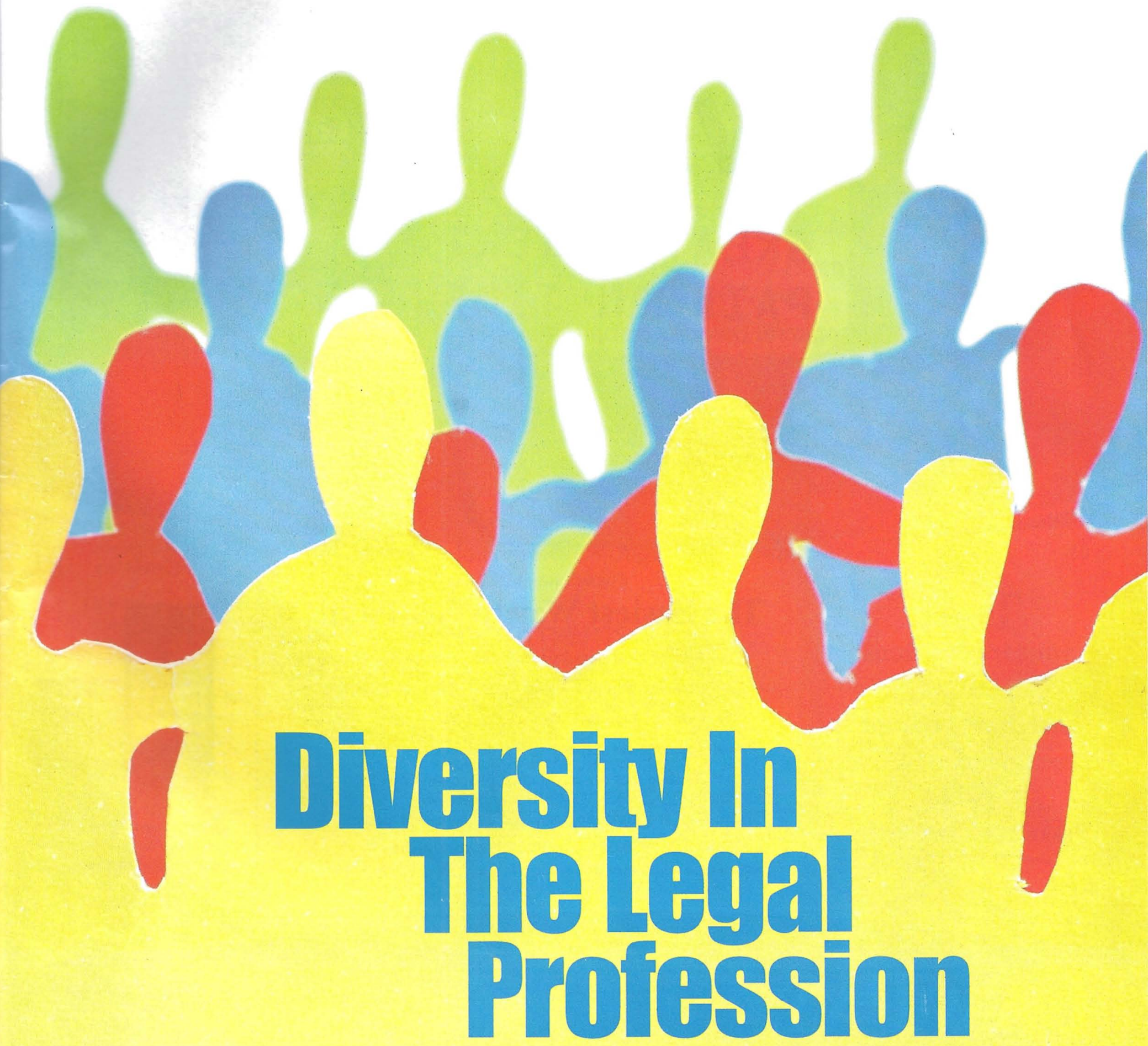




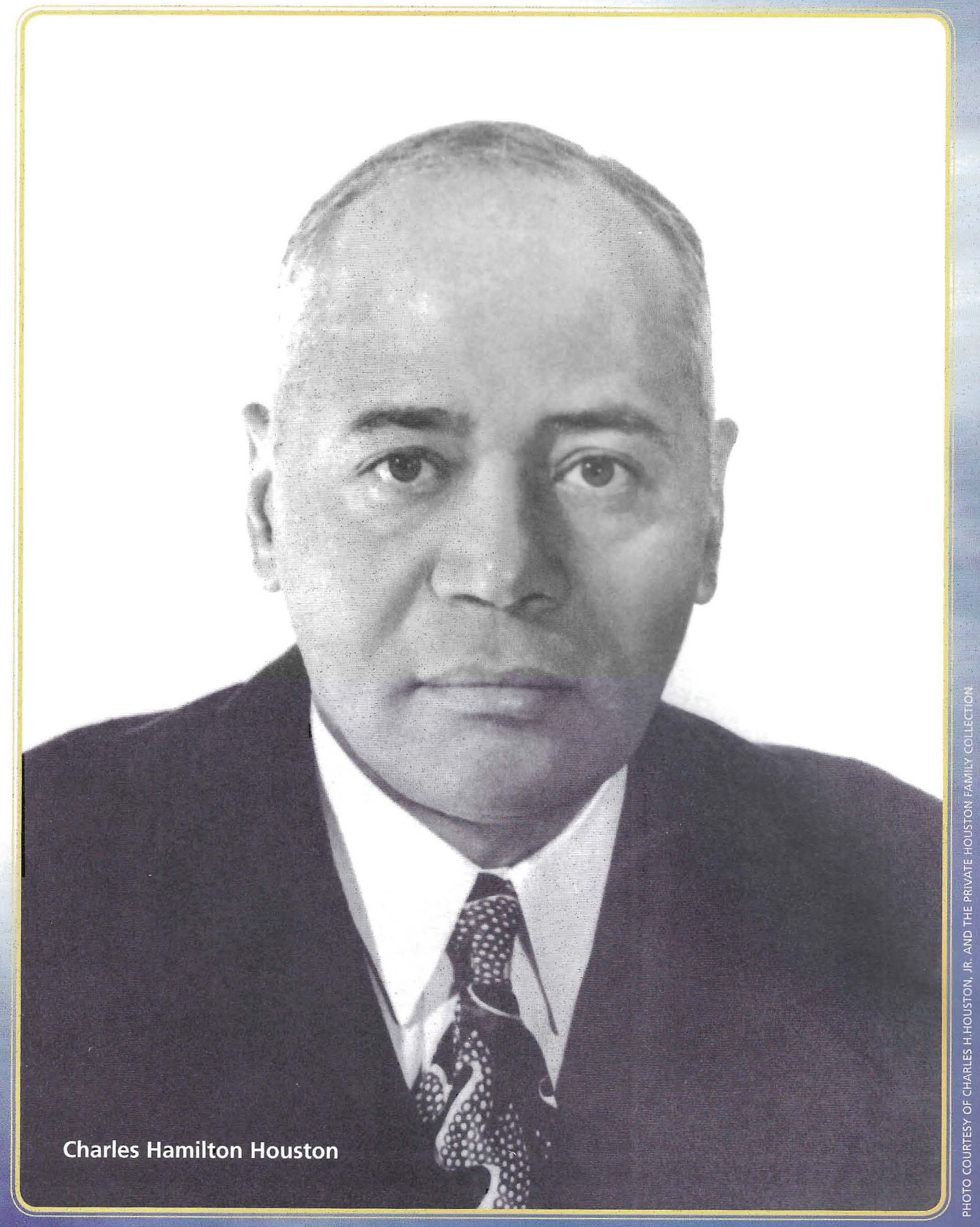




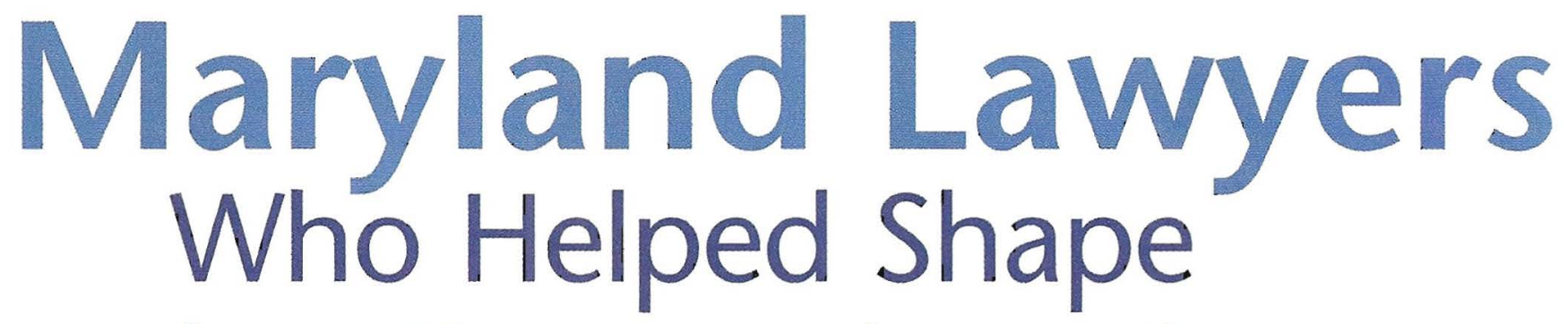

\section{the

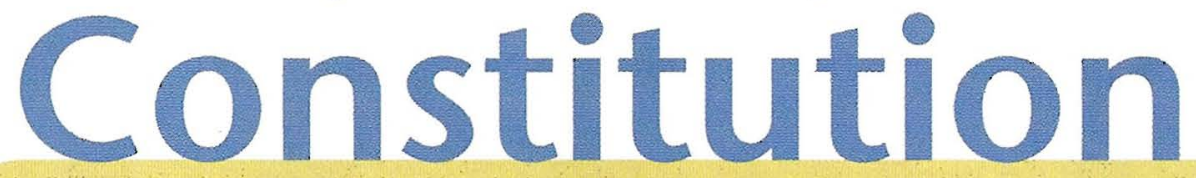 \\ Father of Freedom - \\ Charles Hamilton Houston}

\section{By Jose' Felipe' Anderson}

For most Americans Charles Hamilton Houston is barely a footnote in history. Born in 1896, this Phi Beta Kappa graduate of Amherst College and Harvard educated African-American lawyer went on to win eight of nine cases in the United States Supreme Court. He designed the legal strategy for the historic Brown v. Board of Education decision, Brown v. Board of Educ. 347 U.S. 483 (1954). He was the first African American to be elected to the Harvard Law Review and the first to earn the degree Doctor of Juridical Science Degree. 
By 1950 he would be laid to rest, exhausted by his brutal multi-state law reform agenda that was the hallmark of his 25 year legal career. He would not live to see his efforts to eliminate racial discrimination from the face of the nation's law books completed. Along the way he would work with several legendary Maryland lawyers in cases that were the blueprint for dismantling the sinister practice known as "Jim Crow" that poisoned the nation's ideal of equal justice under law.

The Maryland courtswereHouston's laboratory. This native of Washington D.C. took many short drives and train trips to Maryland to do legal battle. In all, Houston was lead or co-counsel in over a dozen precedent setting cases in Maryland appellate courts. Because the District of Columbia was not a state, Houston needed Maryland to reform equal protection under the $14^{\text {th }}$ amendment to the United States Constitution. His goal was to overturn the flawed "separate but equal" doctrine announced in Plessy v. Ferguson 163 U.S. 537 (1896).

Baltimore born Thurgood Marshall was Houston's star pupil. He would personally train and mentor him to spearhead the battle against racial injustice. Marshall, of course, would ultimately serve the nation as its first African American Solicitor General and United Stated Supreme Court Justice. When Houston was Dean of Howard University law school he took notice of Marshall's potential and began to teach him the legal craftsmanship that would transform civil rights law. He got Marshall a job in the school's law library that allowed him more time to study and pay for his daily train rides from his Baltimore home. He would take Marshall with him to court cases and to meet other important lawyers like the legendary Clarence Darrow and Felix Frankfurter.

Marshall would follow his mentor's lead and become one of the founders of the Monumental City Bar Association, a group of Black attorneys organized at a time when Blacks were not allowed to join either the American Bar Association or the Maryland State Bar Association.

Charles Houston's father, attorney William LePre' Houston was one of the founders of the National Bar Association and became its President once during the 1930s. Charles Houston helped start a similar organization, the Washington Bar Association in the District of Columbia. These associations became invaluable when later; Charles Houston would need local lawyers to file civil rights cases. When Houston left the Deanship of Howard Law School to become the National Association for the Advancement of Colored People's (NAACP) first Chief Legal Counsel, he took Marshall with him to its New York headquarters.

It was from the NAACP national office that Marshall, Houston and another African American lawyer from Baltimore named William I. Gosnell would successfully litigate the case of Donald Gaines Murray who was denied admission to the University of Maryland law school. In a stunning victory after a trial in a Baltimore City courtroom, Judge Eugene O'Dunne ordered the University to admit Murray in what was the NAACP's first major legal victory over racial discrimination with Houston in charge of its legal campaign. The University would appeal to the State's appellate court, but the trial judge's order was upheld. Pearson v, Murray, 182 A. 183 (Md. 1936).
At the time of the case Houston would urge members of the black community to show up in court to support the case dressed in their "Sunday best" to help the press take interest in its importance. For that task he called upon the local NAACP branch president Lillie M.Carroll Jackson and her daughter Juanita Jackson who became NAACP's National Youth Director. Houston worked closely with the energetic and courageous Juanita when they were both at the NAACP national office. He sent her to Scottsboro. Alabama in the 1930 s to meet on behalf of the organization with the defendants in the famous "Scottsboro Boys" cases, where several young black men were falsely accused of raping two white women while all were hitch-hiking on a freight train.

Houston would encourage Juanita to go the law school where she became the first African American women to attend the University of Maryland and the first to be an Editor of its law review: She would later become one of Maryland's greatest lawyers, working on many precedent setting civil rights cases of her own.

She would marry Clarence $M$. Mitchell, Jr. who would serve for many years as the top lobbyist for the NAACP. Clarence Mitchell would also work dosely with Houston on many national civil rights issues in congress. Mitchell, the lawyer/lobbyist, would become known as the $101^{\text {st }}$ Senator as he guided the nation's most important civil rights legislation through congress during the 1960 s culminating in the signing of the Civil Rights Act and the Voting Rights Act by President Lyndon B. Johnson. The historic courthouse in downtown Baltimore where the Murray case was won now bears the name Clarence M.Mitchell Jr. 
Robert A. Gordon, Franklin Lee and Chief Judge

Michael Waring Lee, in the Museum of Baltimore

Legal History, April 18, 1985.

PHOTOGRAPH BY GULLL PHOTO
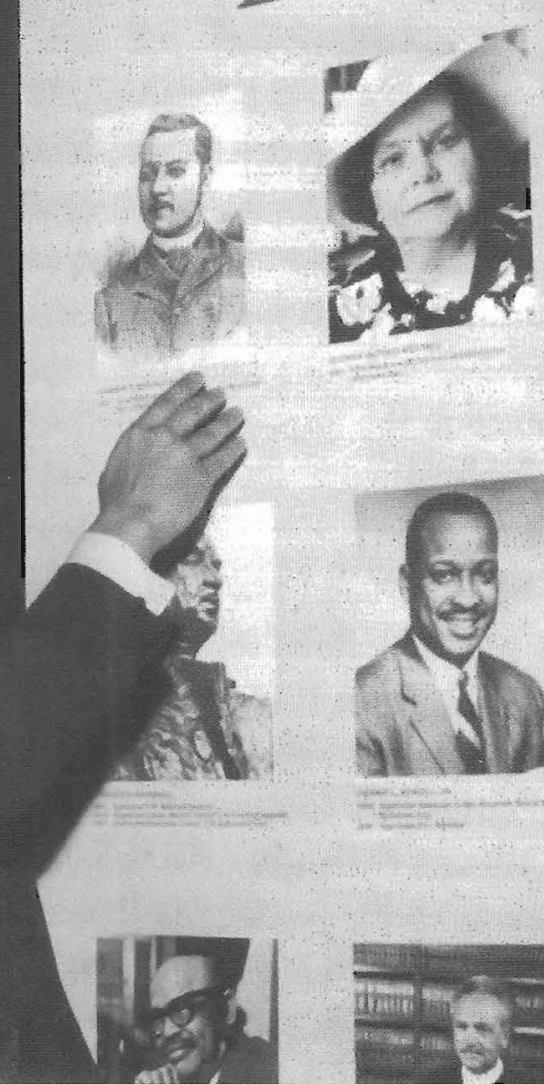

Co
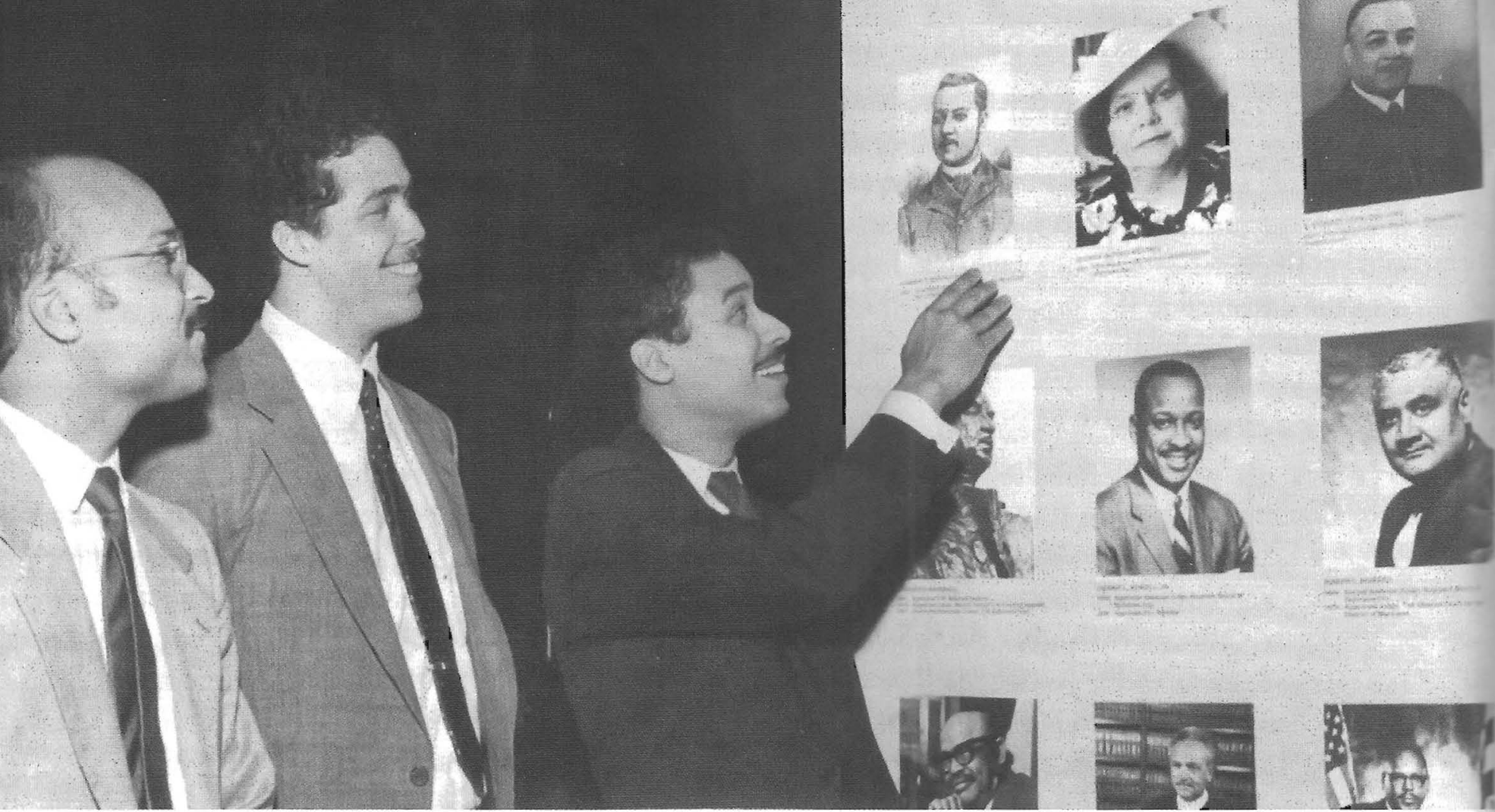

Years after Houston's death Juanita Jackson Mitchell would be part of the legal team representing a teenager named Robert Mack Bell in a famous downtown Baltimore lunch counter sit-in case that would go all the way to the United States Supreme Court. Bell v. Maryland, 378 U.S. 226 (1963). That team also included Robert B. Watts who spent the summer of 1948 law clerking for Charles Houston. Watts would become a well respected Baltimore Circuit Court Judge. A prosecutor in the case, Robert C. Murphy would go on to be the Chief Judge of Maryland.

Today the state's Courts of Appeal Building bears his name. In a touch of extreme irony, Robert Bell, among the Morgan State College students arrested in that protest would go on to Harvard Law School and eventu- ally become the first African American Chief Judge of Maryland's highest court., the Court of Appeals.

William Marbury, a partner in one of Maryland's greatest law firms would encounter Charles Houston while representing the Calvert County school board in law suits involving teacher pay equality. White teachers were paid twice as much as black teachers serving in the same positions during the 1930s. After litigation was filed, the case was ultimately settled. Although Thurgood Marshall played a key role in many of the teacher pay suits across the state, William Marbury recalls that it was Houston who guided the ultimate outcome. In his memoir Marbury would write that he was "deeply impressed by Dr. Houston's handling of this very delicate situation." William L. Marbury, In the
Catbird's Seat (Maryland Historical Society) p.322 (1988).

During the 1930s Marshall and Houston would also represent Communist lawyer Bernard Ades in his disbarment proceedings for trouble Ades allegedly stirred up during the death penalty trial of Euel Lee, on Maryland's eastern shore. Lee was accused of killing the members of a White family he worked for in Berlin, Maryland. Ades persuaded Lee to bequeath Ades his body before Lee's imminent execution, taking it to $\mathrm{New}$ York to display. Ades purpose was to raise funds for the International Labor Defense, the legal representation arm of the Communist Party, that often defended black defendant's free of charge.

Houston saved Ades law license. Houston would argue that Ades' zeal 
in representing a black defendant in a racially charged case deserved some consideration. Judge Soper would rule, "Taking into consideration the unquestioned service rendered in the Lee case, the injuries which the respondent suffered at the hands of lawless men while acting as counsel in that case, and the fact that he has already suffered a suspension from the bar of this court for approximately five months, it is believed that a public reprimand will suffice". In Re: Ades 6 F. Supp. 467(Md.1934).

In another case Houston would rejoin Baltimore lawyers William Gosnell, Dallas Nicholas, the local branch of the American Civil Liberties Union and plaintiff Arnett Murphy of the Baltimore Afro American newspaper family in a lawsuit over Baltimore's segregated golf courses. See, Durkee v. Murphy, 29 A.2d. 253 (Md. 1943). The golf course law suits would not be resolved until nearly five years later in federal court in Law v. Baltimore, 78 F. Supp. 346 (Md.1948) when a federal judge would rule that Baltimore's separate accommodations for Black golfer's were unequal.

Houston would further fight successfully against discriminatory employment practices in the city's public library system, Kerr v. Enoch Pratt Free Library, 149 F.2d. 505 (D.C.212 (4 $4^{\text {th }}$ Cir.1945); residential housing restrictive covenants, Goetz v. Smith, 62 A.2d 602 (Md. 1948); and fight discrimination at the Maryland Institute College of Art, Norris v. Baltimore, 78 F. Supp.451 (D. Md. 1949). In the Norris case, Houston was joined by local lawyers Fred Weisgal, Harry $\mathrm{O}$. Levin, and W.A.C. Hughes who were assisted by a promising Harvard law student named Melvin Sykes. Weisgal would fight many other great civil rights cases in the Maryland Courts

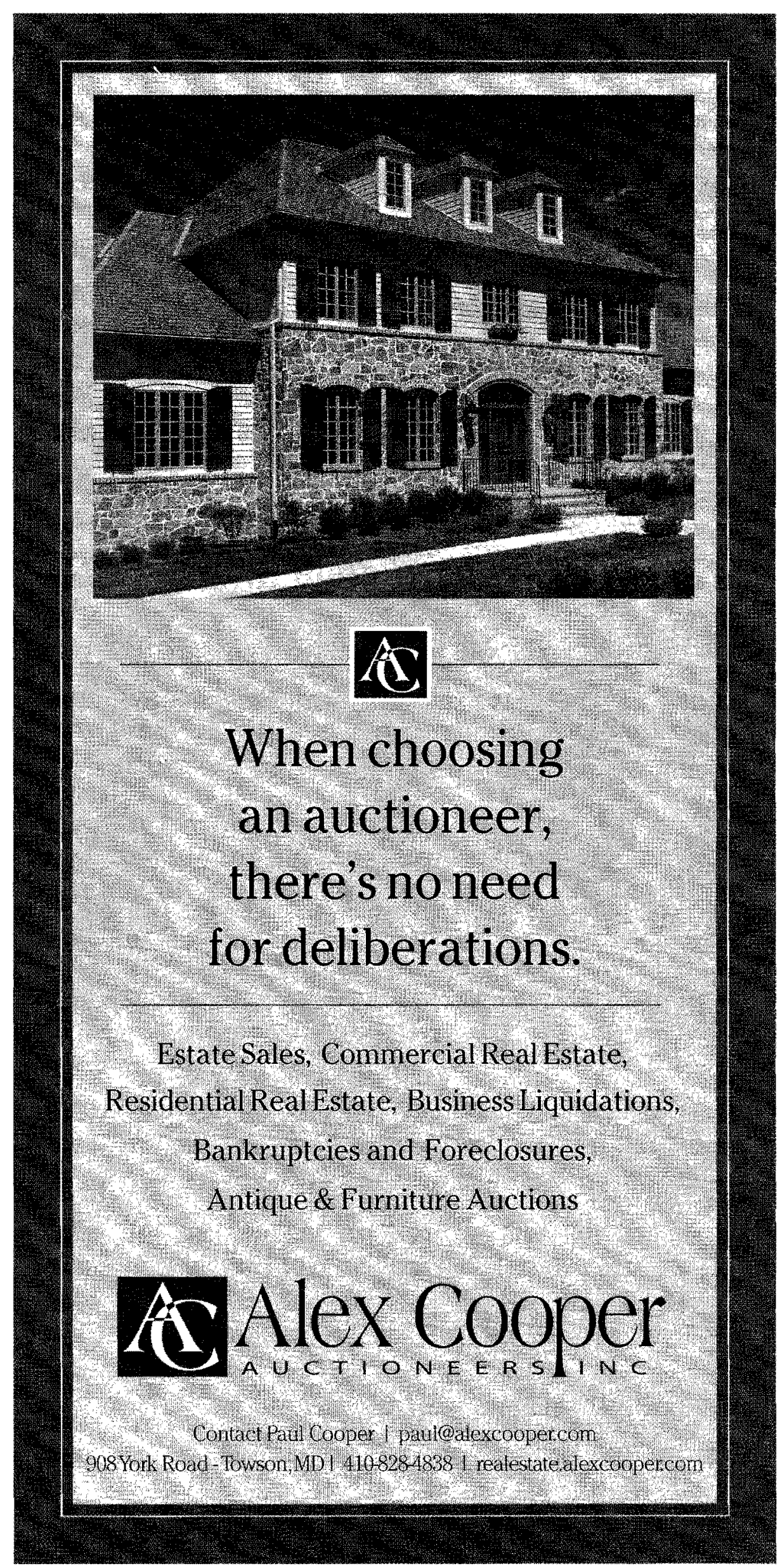




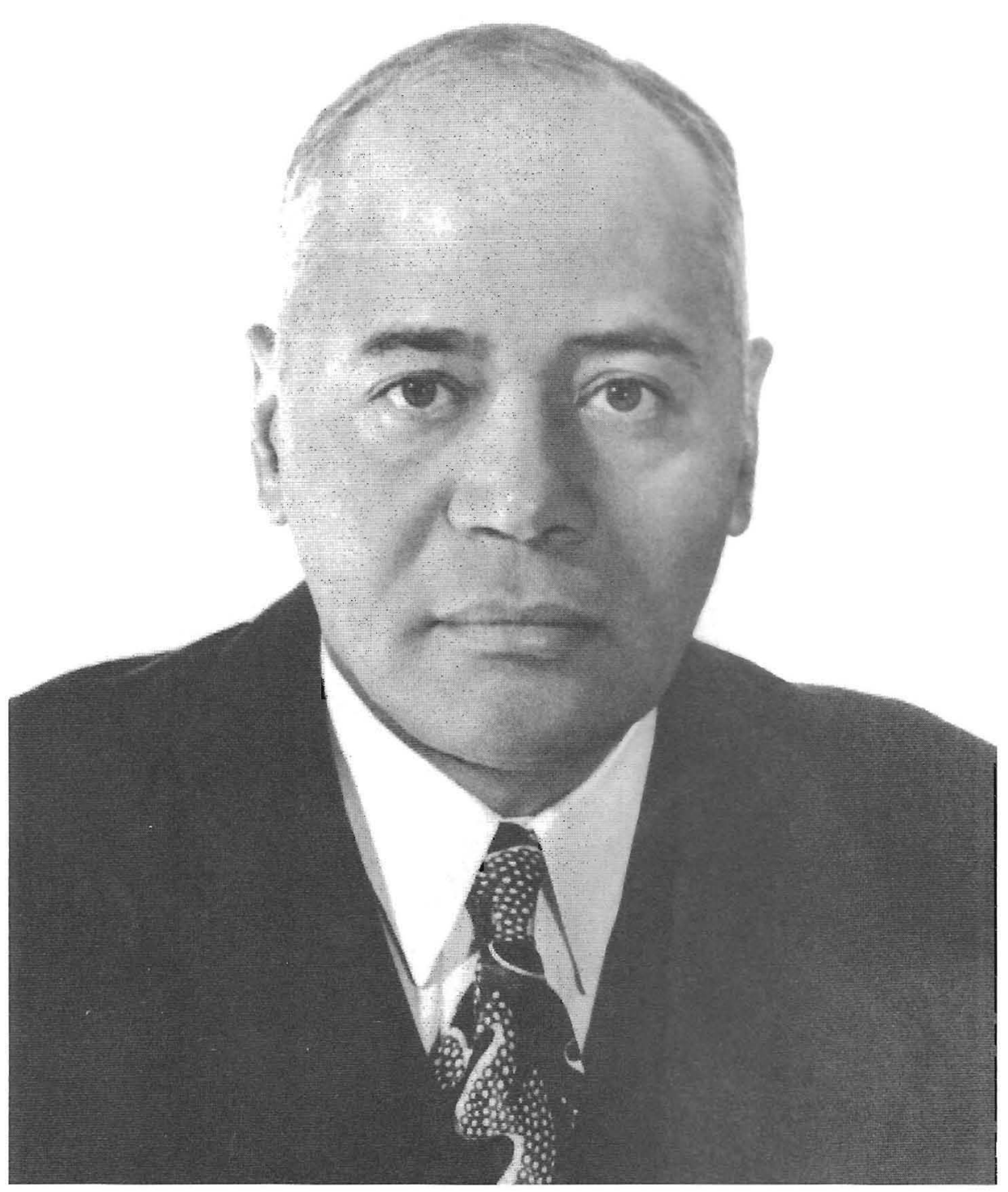

and the Supreme Court of the United States, several on behalf of the ACLU. Hughes would work on many civil rights cases with Houston.

Melvin Sykes who has had an outstanding career as one of Maryland greatest litigators remembers his time with Charles Houston fondly, describing the legendary attorney as extremely bright, pleasant with an understated sense of humor. "I was proud to have worked with him", Sykes said in a summer 2009 telephone interview.

In what could be described as one of the first environmental racism cases, Houston filed suit on behalf of sev- did not prevail, the appellate record of the case demonstrates a keen use of engineers, public documents and expert witness that would rival any modern complex litigation.

Working with him on that case was another promising law student on his summer break named Milton B. Allen. After graduating from law school, Allen would be a founder of the first predominantly African American law firm in downtown Baltimore, Brown, Allen, Watts, Murphy, Russell and Dorsey. The firm would become the first to integrate its legal staff with the hiring of associate Stephen Harris in the early 1960 's. Harris would later become Maryland's State Public Defender.

Milton Allen would be elected the first African American State's Attorney in Baltimore City in1970 and the first to hold the job of chief prosecutor in any major U.S. city. He would later serve as a Circuit Court judge. In a 1976 interview Milton Allen would describe Houston as a brilliant man who was far ahead of his time.

In 1947 Houston would join forces with local attorney William. H. Murphy Sr. in the representation of Eugene James in a death penalty case involving the tragic murder of an eleven year old girl in Northwest Baltimore City. James v. State, 65 A.2d. 888 (Md. 1949). Attempting to establish what could be described as a "diminished capacity defense" the legal team called five mental health experts and used for the first time in Maryland history the Rorschach ink blot test in their defense strategy. They battled in the case against an outstanding team of trial lawyers that included lead counsel Anselm Sodaro and Allan Hamilton Murrell.

The strategy did not prevail but at the conclusion of the case Judge M. 
Herman Moser commented that no finer lawyer than Houston had ever appeared in his courtroom. Sodaro won many high profile prosecutions and served for many years with great distinction as a Baltimore County Circuit Court judge. The Maryland State Bar Association has honored his memory with an award for judicial civility in his name. After a brilliant career as a defense attorney following the James trial, Murrell was called upon to establish the first statewide public defender system in the 1970's. He served as its leader for 20 years.

In his final legal victory, Houston would leave his hospital bed in Washington D.C. to finish his battle against "Jim Crow" that he started in a lawsuit against the University of Maryland School of Nursing in downtown Baltimore. Esther McCready sought admission to the school rather than accepting a scholarship to a segregated school out of state.

McCready v. Byrd, 73 A.2d 73 A.2d 8 (Md.1949). In that case he was cocounsel with Donald Gaines Murray, the very same man who he had fought to get admitted to Maryland law school fifteen years earlier as NAACP chief Counsel.

Sadly, Houston died of heart failure a few days after McCready brought him news of the victory to his hospital room. Houston's national impact on equal protection of the law is clear. Equally clear is the impact he had on the Maryland Courts and the lawyers who worked with him to establish many of those groundbreaking legal principles.

Thurgood Marshall would say that he was responsible for all the groundwork of the NAACP's civil rights litigation and that no amount of credit would be enough. William $\mathrm{O}$. Douglas, the longest serving Justice in United States Supreme Court history would say that he was one of the finest lawyers to ever appear before the Supreme Court. The Howard University School of Law Building is named for Houston and the school is currently lead by Baltimore native and former Mayor Kurt L. Schmoke who is now its Dean. The University of Baltimore has presented several lifetime achievement awards in litigation that bear his name. In 2009 the United States Postal Service issued a stamp in his Honor.

Mr. Anderson is a Professor of Law at the University of Baltimore School of Law and an Adjunct Professor of Legal Studies and Business Ethics at the University of Pennsylvania's Wharton School. He may be reached at janderson@ubalt.edu

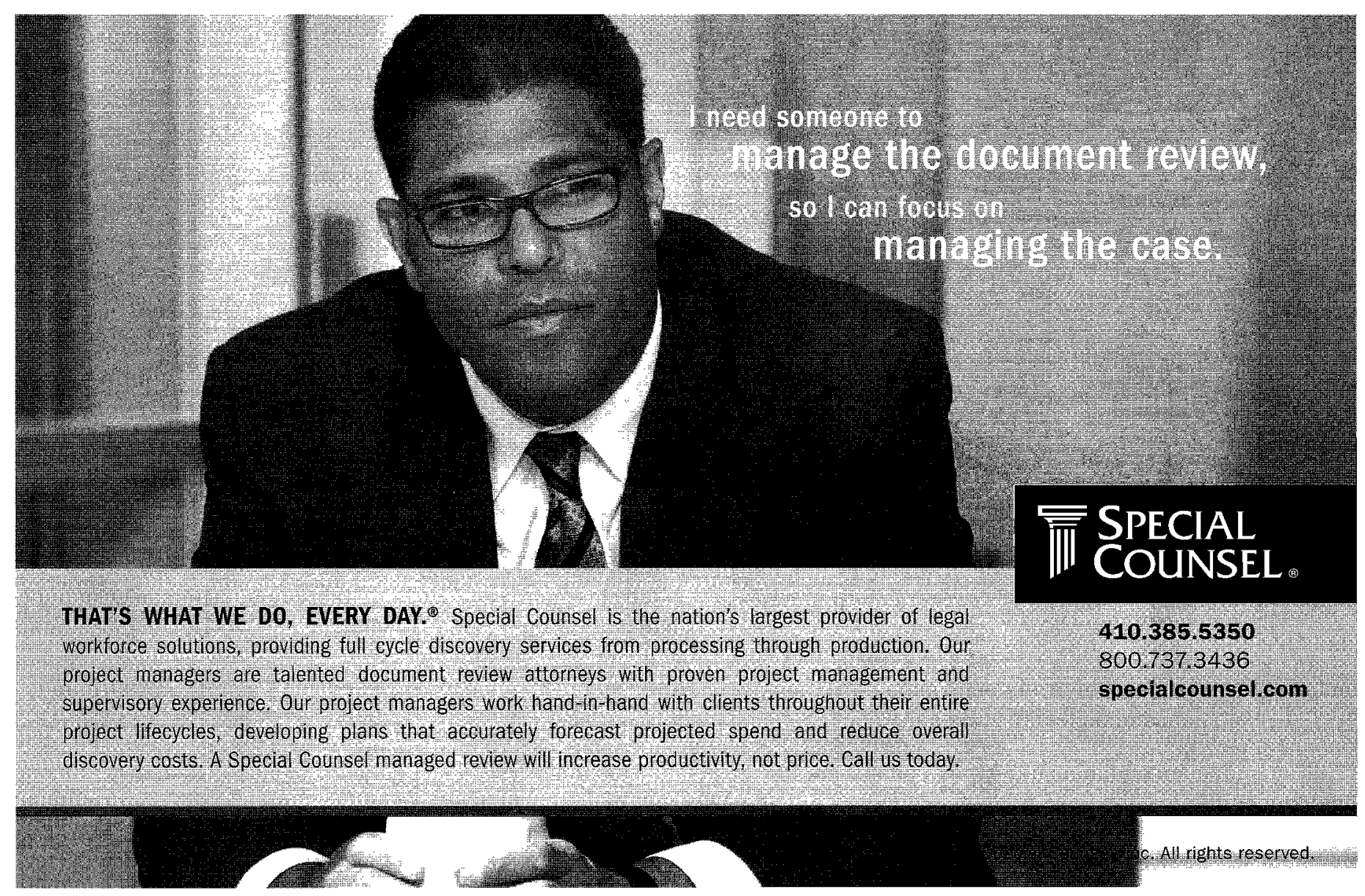

